\title{
First Exploration on Interactive Teaching of Artistic Design Course - Take Font Design Course for Example
}

\author{
Chen Chen \\ Lijiang College of GuangXi Normal University, Guilin Guangxi, 541004, China
}

Key words: Micro-course, Font design course, Interactive teaching, Teaching reform.

\begin{abstract}
This paper discusses the necessity of interactive teaching mode in modern artistic design course teaching based on the micro-course and MOOC phenomenon popular in recent years, takes Font Design, the course taught by the author in recent years, for example, puts forward four new ways and methods of interactive teaching mode: establishment of course objectives with incentive system; "precise" positioning of teaching contents; introduction of excellent micro-course aided teaching based on features of information era; establishment of course introspection, and conducts in-depth analysis and exploration based on the specific situation of teaching and students' work cases.
\end{abstract}

\section{Introduction}

Network micro-course has suddenly become popular in recent years. Network micro-course led by public design websites such as "Young Designer School" and "Hey Design Association" has become unprecedentedly popular among young designers and students from fine art colleges. Micro-course is a new network course resource established and generated based on disciplinary knowledge points. Micro-course centering on "micro-video" includes supportive and extensive resources matched with teaching such as micro-teaching plan, micro-exercise, micro-courseware, micro-introspection and micro-comment, thus forming a semi-structural, web, open and situational environment of dynamic resource generation and interactive teaching application. (1)Under the promotion of the general trend, I signed up for a plate design experience course for the first time one day at the end of 2015. In the course with Wechat as platform, 300 people watched teachers' explanation and comment on plate design works and summary of plate design method in a live form combining voice and pictures. The course lasted for nearly 60 minutes. Besides sharing with regular image-text combined with voice, questioning link was provided. It was beyond my expectation that there were many people asking questions, involving specific operating mode, discussion on design aesthetics, doubt about future way and expectation for teachers to provide advance courses. The teacher answered questions with clear sequence of thought, explained cases with appropriate order and had strong ability of practical operation. I was a little amazed. In surprise, I found after class that the teacher was one year younger than me but was extraordinary. He was a contemporary senior graphic brand designer, the author of a famous best seller Design Diary of Designer, the founder of Qianyidengming brand studio, research and development person and lecturer of Qianyidengming \& online interactive design course and special designer of ZCOOL, who has held online training course and campus tour lecture for multiple times and had numerous students. This course was just like a small stone put into the lake. The ripples seemed calm but would become greater and greater. As a designer and teacher, I have been inspired from network micro-course.

Specialized courses of art students are always more difficult than other majors, the reason of which is personality. Ranging from the personality in being late and leaving early, riddling self-confidence "I think that I am the best" to the personality in attending class based on emotion and interest, numerous reasons make art students different and numerous art students make courses of art category 
headachy. Many teachers have constantly rethought teaching method, reformed course content, modified teaching outline, improved classroom language vitality and introduced practical teaching so as to make class well and allow students to enter the classroom voluntarily. However, while theoretical improvement has been made a lot and a lot of theses have been written, it is really difficult to make class well and allow students to get up and attend class voluntarily in the morning and do homework willingly in the evening. I think of what I saw on network micro-course: college students never getting out of school, designers of advertising agency and a 50-year-old woman engaged in printing spent money on the class and were never absent from class, handed in homework in time, communicated and discussed with others positively and accepted others' opinions with an open mind. Their enthusiasm about learning design is really surprising. Inspired by Plate Design micro-course, I have made appropriate adjustment and conducted experiment in my own teaching. I do not consider it as teaching reform since it is not a mature theoretical system, but it makes teaching and learning interesting. I think that it is more like a kind of exchange and interaction which is popular currently. It pays attention to effective information exchange, feeling replacement and collaboration. In such new classroom teaching, the atmosphere becomes joyful and design works have better effect. It is most difficult that I, as the teacher, have integrated into the classroom and got recognition through collaboration with students. Now I share these experience with you while taking Graduation Design Font Design course for example.

\section{Establish course objectives with incentive system}

Just as work objectives, we should know what to do, what can be done and what can be got after doing in each stage. The establishment of course objectives should be controlled by teachers. A course objective with incentive system can allow students to have learning motivation more easily. Currently, most students have nothing to worry about and their employment pressure is shared by their family members. Except students who can be admitted to domestic top art colleges, the reason of half students choosing art major is due to hobby and easier way to enter a high school. As teachers, we must face such reality because knowing the situation of students is an important condition for pertinent establishment of course objectives. What does professional learning mean to students? Outstanding performance? Good work? Personal honor? Or gradually penetrated life cultivation? I think that self-value identification is the source power of our advancement in whichever age group. We need to be identified by parents, teachers, classmates, partners, leaders and the society. Therefore, a specialized course with value of identification is a good incentive method. Small class- and faculty-level competitions and large district- and national-level design competitions with high value are good course objectives. For example, we have introduced Founder Font Design Competition in font design course teaching, set up course work with participation and signup requirements and planned course time according to time stipulation of competition. Founder font design competition is the most influential design competition with the largest scale and greatest appealingness in the field of Chinese font design. Since it was first held in June 2001, it has been held for over 10 times successfully and gathered the most creative font design works in all walks of life in China. With participation in such competition as the objective, students can have a sense of mission arising spontaneously. The high specification of competition makes the aspiration of learning fuller and teachers will put more energy correspondingly.

\section{"Precise" positioning of teaching contents}

The word "precise" occurs in each major network media frequently. "Precise" is more appropriate to art which is a characteristic major emphasizing personality. As is known to all, art course involves small-class teaching. The reason is that art is a major requiring personality and advocating creativity and distinctiveness. There are no absolute good or bad and even no absolute right or wrong at most time. It differs greatly from other disciplines requiring standard answer. Teaching of such major must be based on different strong points, professional level and understanding ability of each student. 
One-to-one and one-to-group (generally 3 to 5 persons) in class are most common, which aim at giving specific teaching opinions according to different design contents and thoughts of each student.

For example, a student designed a font called as Ripples in font design course. This font name was created by himself. In the preliminary design and positioning phase, he told me the reason for designing such font, i.e. the original intention of designing such font was to record a spiritual feeling of ripples in stagnant water. Such creative font design has integrated his journey of the heart in college life: the cruel reality and firmness of future dream are interwoven and nothingness in the reality and ideal deep in heart can hardly be balanced. Therefore, the font presents a state of pain and twist with strokes wandering. Another student designed a font called as Moonlight. Its design is defined as the creation of a wonderful elegant and flowing font with human customs and an artistic conception as misty moon shine according to the feeling of reading Prelude to Water Melody of ancient poet Su Shi and Moonlight over the Lotus Pond of modern literary giant Zhu Ziqing. The design content and theme selected by the two students mentioned above differ greatly: one resolute and rebellious, the other mellow and hazy. Same teaching guidance over the two students would make a fool. Therefore, "precise" positioning of teaching individuals and contents is an effective classroom teaching method. One-to-one communication and exchange can allow teachers to master the personality of students more accurately and understand their thoughts in communication, make teaching like casual chat among friends, establish equal information replacement, avoid commanding impartment of textbook knowledge and promote learning initiative and confidence in gradual design thought exchange. We will see the distinct but personalized excellent font design works by the two students.

\section{Introduction of excellent micro-course aided teaching based on features of information era}

I introduced the micro-course learning class that I attended and the micro-course inspired my teaching. Therefore, I think more about why not introduce excellent micro-course into classroom teaching. In the information era, the field of vision determines the starting point of design and learning resources influence the level of design. Internet makes the world close enough to reach. Famous teachers and classes are no longer far away. Abilities of a teacher are limited, but many experts and teachers in the field of design can give the most professional solution for different problems, which is so joyful. Therefore, it is win-win to share good micro-course with students under the basic teaching specification and allow the latest and best information to exert its due value. In my font design course phase, I have participated in the learning of multiple micro-courses with students, such as Font Design in Logo Design of Li Ying, Ten Years Ten Cases of Zheng Zhong and Font Vigor. Most teachers are design director of a advertisement company with rich practical experience. Their methods and knowledge are of great help to teachers and students. Teachers are not all-purpose. Teachers of artistic design should constantly improve their professional ability, absorb new information and have good works to make students convinced. Therefore, learning while teaching and even joint learning become a new concept of teaching in this era. The same classroom, the same feeling, joint efforts to overcome difficulties and joint teaching and problem solving make me feel that teaching is more smooth and natural. There are more students daring to raise questions and willing to discuss design with me, think and innovate.

\section{Establishment of course introspection}

Introspection here not only refers to self-reflection of teachers, but also means introspection of all students to course and design works. Some people often say, "result is not important, while process is.” But I don't agree with it. Let’s take design for example. A logo design scheme for bidding will probably never be seen by the world if not winning even though you have stayed up for half a month with great efforts. Therefore, we must try every means to conduct market research well, make customer demand certain, make beautiful design and wonderful presentation and make design works be published and selected rather than eliminated. The result is very important. Without beautiful 
result, the process will lose its color. Introspection on the reason of success and failure is an indispensable part of course summary. Schools are always advocating practical teaching. Practice is a standard for testing truth. Therefore, putting design in the market and allowing competition judges to analyze and test it is of great help to students' understanding of design and market. Works not winning a prize in various design competitions are not necessarily bad works, but most works winning a prize are good works. We should be good at analysis and learn introspection in teaching. Let's take font design course for example. There were 26 works submitted for competition, 6 selected for the next round and 2 winning the prize. In which aspect did works selected for the next round and winning the prize succeed? Why did other works stand out? We select typical cases and conduct discussion and analysis. Moonlight Font makes people feel personally on the scene due to its exquisite artistic conception of font design. Character strokes further evolve based on ancient seal character. It can both break and continue tradition and therefore are well-reputed. Ripples Font has become popular due to its flexible and convergent strokes and appropriate characteristic expression of the author.

As mentioned before, practice is a standard for testing truth. I have explored and practiced with my own teaching and have introspection on the "good" and "bad" obtained. Though the course was over, the "ripples" in my mind are spreading. Wish wonderful "moonlight” will illuminate the future way.

\section{Acknowledgement}

Topic: fund project of undergraduate teaching reform engineering of Guangxi higher education in 2015, Study and Practice of Studio System Teaching Mode for Art Design Major in Independent Colleges (2015JGB472).

\section{References}

[1] Su Xiaobing, Guan Yuqi. Analysis on Micro-course Concept and Study on Its Application in Teaching, Learning Resources and Technology Module, 95, PP. 1006-9860 （2014） 07-0094-06. 